\author{
G.A. Yessenbayeva ${ }^{1}$, A.T. Kasimov ${ }^{2}$, B.A. Kasimov ${ }^{1}$ \\ ${ }^{1}$ Buketov Karaganda State University, Kazakhstan; \\ ${ }^{2}$ Karaganda State Technical University, Kazakhstan \\ (E-mail: esenbaevagulsima@mail.ru)
}

\title{
On the calculation of round plates for bending
}

\begin{abstract}
The article is devoted to the study of bending of round plates, which are the basis for calculating many problems of mechanics. In the article the structure of this method is presented, its main components are highlighted; its types are characterized, as well as its classical approaches. In this article the research of the bending problem for round plates is carried out in particular cases. Methods of bending calculation of round plates like all analytical methods have a number of advantages, which are also noted in this article. The article is focused mainly on mechanics, engineers and technical specialists.
\end{abstract}

Keywords: round plate, plate deflection function, axisymmetric loads, maximum deflection of the round plate.

Plates are widely used now in various fields of technology: construction, engineering, aviation, shipbuilding, etc. During operation, the plates are subjected to temperature, chemical, force and other influences. These effects cause plate deformations. Therefore, the problem of calculating the plates are so diverse and have such a different character [1-6].

Many structural elements, such as the bottoms of pistons, tanks, apparatus, hatches, various kinds of covers; flanges; diaphragms, etc. [7], are round plates. The simplest form of deformation for such elements is their bending [8-12].

We consider the bending of a round plate and several axisymmetric loads: $P$ is the concentrated force at the center of the plate, $T$ is the ring load, $q$ is the distributed load.

We denote by $h$ the thickness of the plate, which can be constant or variable. The outer radius of the plate is denoted by $R$. Vertical linear displacements of the mid-plane points (along the $z$-axis) are called deflections and are denoted by the letter $W$.

For thin plates, the assumptions called Kirchhoff hypotheses are valid [13].

We will distinguish two directions in the plate:

- the radial direction (all parameters of this direction are denoted by the index $« r)$ ),

- the circumferential direction (all parameters of this direction will be marked with the index « $\varphi »$ )

According to Kirchhoff's hypotheses for radial and circumferential deformations, we obtain

$$
\varepsilon_{r}=z \frac{d \varphi}{d r}, \quad \varepsilon_{\varphi}=\varphi \frac{z}{r}
$$

Then from Hooke's law for the plane stress state $\left(\sigma_{r} \neq 0, \sigma_{\varphi} \neq 0, \sigma_{z}=0\right)$ it is followed

$$
\sigma_{r}=\frac{E z}{1-\nu^{2}}\left(\varphi^{\prime}+\nu \frac{\varphi}{r}\right), \quad \sigma_{\varphi}=\frac{E z}{1-\nu^{2}}\left(\nu \varphi^{\prime}+\frac{\varphi}{r}\right)
$$

The relationship between the deflection and the angle of rotation is written as

$$
W^{\prime}=-\varphi
$$

Normal stresses $\sigma_{r}$ are grouped in the bending moment $M_{r}$, and $\sigma_{\varphi}$ are grouped in the bending moment $M_{\varphi}$

$$
M_{r}=D\left(\varphi^{\prime}+\nu \frac{\varphi}{r}\right), \quad M_{\varphi}=D\left(\nu \varphi^{\prime}+\frac{\varphi}{r}\right)
$$

where $D$ is cylindrical rigidity of the plate. 
Tangential stresses from the platform of the unit width form a transverse force $Q$ in the circumferential section. The normal stresses are easily expressed in terms of bending moments. It is sufficient to substitute expressions (3) in (1). Then we receive

$$
\sigma_{r}=\frac{M_{r}}{J} z, \quad \sigma_{\varphi}=\frac{M_{\varphi}}{J} z
$$

where $J=\frac{h^{3}}{12}$ is the moment of inertia for a rectangular strip of unit width.

The signs rule of the bending moment for round plates: we assume that the bending moment is positive if the upper layer of the plate is stretched.

With axisymmetric bending, the problem of calculating a round plate is significantly simplified, since in all equations and formulas describing the bending of the plate, the derivatives with respect to the angular coordinate are equal to zero. Therefore, the differential equation of plate bending takes the following form

$$
\frac{d^{4} W}{d r^{4}}+\frac{2}{r} \frac{d^{3} W}{d r^{3}}-\frac{1}{r^{2}} \frac{d^{2} W}{d r^{2}}+\frac{1}{r^{3}} \frac{d W}{d r}=\frac{q}{D}
$$

The equation (4) is a differential equation of Euler.

In the case of plate equilibrium under the action of efforts $M_{r}, M_{\varphi}, Q$ and the acting load $q$ on the center of the plate, it is possible to obtain the differential equation of the problem in a simpler form. Making two equilibrium equations, we obtain

$$
r \varphi^{\prime \prime}+\varphi^{\prime}-\frac{\varphi}{r}=\frac{Q}{D}
$$

This is an ordinary second-order linear differential equation of second order with respect to a function for the angle of rotation, and the resolving equation for axisymmetric bending through the function of deflection is the equation of the fourth order. The general solution of the equation (5) takes the form

$$
\varphi=\frac{C_{1}}{r}+C_{2} r+\frac{1}{D} \int_{r_{0}}^{r} \frac{r^{2}-s^{2}}{r} Q(s) d s .
$$

The calculation of bending for circular plates with constant thickness

We consider the pure bending of a solid round plate by moments distributed along the hinge-supported contour. In this case, there is no transverse load. The transverse (cutting) force also equals zero: $Q=0$ and we have $M_{r}=M_{\varphi}=m$, then the deflection of any point from equation (2) is equal to

$$
W=C-\frac{m}{2 D(1+\nu)}\left(r^{2}-r_{o}^{2}\right) .
$$

The constant $C$ is found from the boundary condition of the contour fixing.

In the case of hinged fastening the contour at $r=R$ we have $W=0$. If $C$ equals zero $(C=0)$ and $r_{0}=R$, the condition of the hinged fastening is satisfied. Then the following formula is valid

$$
W=\frac{m}{2 D(1+\nu)}\left(r^{2}-r_{o}^{2}\right)
$$

The greatest deflection (at $r=0$ ) is

$$
W_{\max }=\frac{m R^{2}}{2 D(1+\nu)} .
$$

We consider a round plate under the action of a concentrated force $P_{0}$ at its center. In this case we have

$$
Q(s)=\frac{P_{0}}{2 \pi s}
$$

Substituting (6) into the formula of the particular solution (5), we get

$$
\varphi_{1}=\frac{P_{0}}{4 \pi D}\left[r \ln \frac{r}{r_{0}}-\frac{1}{2 r}\left(r^{2}-r_{0}^{2}\right)\right] .
$$


Then the general solution can be written as

$$
\varphi=\frac{C_{1}}{r}+C_{2} r+\frac{P_{0}}{4 \pi D}\left[r \ln \frac{r}{r_{0}}-\frac{1}{2 r}\left(r^{2}-r_{0}^{2}\right)\right] .
$$

We will find $C_{1}, C_{2}$ from boundary conditions. If $r=0, \varphi=0$, then from (7) we determinate $C_{1}$

$$
C_{1}=-\frac{P_{0}}{8 \pi D} r_{0}^{2}
$$

If $r=R, \varphi=0$, then from (7) we find $C_{2}$

$$
C_{2}=\frac{P_{0}}{4 \pi D}\left(\frac{1}{2}-\ln \frac{R}{r_{0}}\right) .
$$

As a result, the general solution takes the form

$$
\varphi=\frac{P_{0} r}{4 \pi D} \ln \frac{r}{R}
$$

We calculate the bending moments

$$
M_{r}=-\frac{P_{0}}{4 \pi}\left[1+(1+\nu) \ln \frac{r}{R}\right], \quad M_{\varphi}=-\frac{P_{0}}{4 \pi}\left[\nu+(1+\nu) \ln \frac{r}{R}\right] .
$$

In the center of the plate, if $r=0$ then $\ln \frac{r}{R} \rightarrow \infty$ and therefore, the values of bending moments tend to infinity. On the edge of the plate, if $r=R$ then $\ln 1=0$, and we have that the abcolute values of bending moments are equal to

$$
M_{r}=\frac{P_{0}}{4 \pi}, \quad M_{\varphi}=\frac{P_{0} \nu}{4 \pi} .
$$

Infinitely large values of bending moments are only a consequence of the extreme schematization for the mathematical model of the problem (the concentrated force is applied at the point) [13]. In fact, this does not happen, the load is distributed over a small platform, and in a small neighborhood of the point of force application we have $M_{r}=M_{\varphi}$, as in all other cases of loading [14].

We consider the general differential equation of plate bending

$$
\frac{d^{4} W}{d r^{4}}+\frac{2}{r} \frac{d^{3} W}{d r^{3}}-\frac{1}{r^{2}} \frac{d^{2} W}{d r^{2}}+\frac{1}{r^{3}} \frac{d W}{d r}=\frac{q}{D} .
$$

The general solution of the differential equation (8) has the form

$$
W(r)=C_{1}+C_{2} \ln r+C_{3} r+C_{4} r \ln r+W_{1}(r)
$$

where $W_{1}(r)$ is a partial solution of the equation (4). To find a particular solution, we present equation (4) as

$$
\frac{1}{r} \frac{d}{d r}\left[r \frac{d}{d r}\left(\frac{1}{r} \frac{d}{d r}\left(r \frac{d W}{d r}\right)\right)\right]=\frac{q(r)}{D} .
$$

After integration (9) we obtain

$$
W_{1}(r)=\frac{1}{D} \int_{a}^{r} \frac{1}{\xi} d \xi \int_{b}^{\xi} \eta d \eta \int_{c}^{\eta} \frac{1}{\zeta} d \zeta \int_{d}^{\zeta} q(\tau) \tau d \tau
$$

For the case when the plate is under the action of a uniformly distributed load $q=$ const, after integration (10) we have

$$
W_{1}(r)=\frac{q r^{4}}{64 D} .
$$

Included in (8) constant of integrations $C_{1}, C_{2}, C_{3}$ and $C_{4}$ are determined from the corresponding boundary conditions in each specific problem. 
We consider the problem of bending for a round plate, rigidly pinched along the contour. This plate is under the action of a uniformly distributed load $q$. The deflection of the plate is determined by the expression (8), where the particular solution has the form (11).

In accordance with the physical meaning of the problem in the center of the plate at $r=0$ deflection and internal forces must have finite values. To satisfy this condition, it is necessary to remove the partial integrals containing the natural logarithm in the general solution (8), putting the constant integrations $C_{2}$ and $C_{4}$ equal to zero. Thus, we obtain the following expression for the deflection of the plate

$$
W(r)=\frac{q}{64 D} \cdot r^{4}+C_{1}+C_{3} r^{2}
$$

To determine the constants $C_{1}$ and $C_{3}$, we use the boundary conditions on the rigidly clamped plate contour

$$
r=R ; \quad W=0 ; \quad \varphi=\frac{d W}{d r}=0 .
$$

Using these conditions, we obtain two algebraic equations with respect to $C_{1}$ and $C_{3}$. Having solved these equations, we receive

$$
C_{1}=\frac{q \cdot R^{4}}{64 D}, \quad C_{2}=-\frac{q \cdot R^{2}}{32 D}
$$

The final expression for the deflection is determined by the following formula

$$
W=\frac{q \cdot r^{4}}{64 D}-\frac{q \cdot R^{2} \cdot r^{2}}{32 D}+\frac{q \cdot R^{4}}{64 D}=\frac{q}{64 D}\left(R^{2}-r^{2}\right)^{2}
$$

Then we get the expressions for the internal forces in the plate in the form

$$
\begin{gathered}
M_{r}=\frac{q}{16}\left(R^{2}(1+\nu)-r^{2}(3+\nu)\right), \\
M_{\varphi}=\frac{q}{16}\left(R^{2}(1+\nu)-r^{2}(1+3 \nu)\right), \\
Q=-\frac{q r}{2} .
\end{gathered}
$$

In the center of the plate, the bending moments are equal to each other, the transverse force is zero, and the deflection has a maximum value equal to

$$
W_{\max }=\frac{q \cdot R^{4}}{64 D}
$$

If $r=R$ we find the moments on the plate contour

$$
M_{r(r=R)}=-\frac{q \cdot R^{2}}{8} ; \quad M_{\varphi(r=R)}=-\frac{q \cdot R^{2}}{8} \nu .
$$

On the center of the plate, where $r=0$, we have

$$
M_{r}=M_{\varphi}=\frac{q \cdot R^{2}}{16}(1+\nu) .
$$

The maximum stress on the plate contour is equal to

$$
\sigma_{r \max }=-\frac{6 M_{r}}{h^{2}}=\frac{3}{4} \frac{q \cdot R^{2}}{h^{2}} .
$$

In accordance with the condition of rigidity [14]

$$
\sigma_{r \max }=\frac{6 \cdot M_{r \max }}{h^{2}} \leq[\sigma]_{\text {bend. }}-5 \%
$$

we make the adjustment of section thickness $h$. 
The round plate has a supported edge. Uniformly distributed in a circle of radius $b$ the load $P$ acts on the plate. In this case, the expression for the function $W(x, y)$ has different forms for $r>b$ and $r<b$

$$
\begin{gathered}
W_{r>b}=\frac{P}{8 \pi D}\left[\left(r^{2}+b^{2}\right) \ln \frac{r}{a}+\frac{(3+\nu) a^{2}-(1-\nu) b^{2}}{2(1+\nu) a^{2}}\left(a^{2}-r^{2}\right)\right], \\
W_{r<b}=\frac{P}{8 \pi D}\left[\left(r^{2}+b^{2}\right) \ln \frac{b}{a}+\frac{(3+\nu) a^{2}-(1-\nu) b^{2}}{2(1+\nu) a^{2}}\left(a^{2}-r^{2}\right)+r^{2}-b^{2}\right] .
\end{gathered}
$$

For a plate with a pinched edge at the same load $P$ for the function $W(x, y)$, we have [15]

$$
\begin{gathered}
W_{r>b}=\frac{P}{8 \pi D}\left[\left(r^{2}+b^{2}\right) \ln \frac{r}{a}+\frac{a^{2}+b^{2}}{2 a^{2}}\left(a^{2}-r^{2}\right)\right], \\
W_{r<b}=\frac{P}{8 \pi D}\left[\left(r^{2}+b^{2}\right) \ln \frac{b}{a}+\frac{a^{2}+b^{2}}{2 a^{2}}\left(a^{2}-r^{2}\right)+r^{2}-b^{2}\right] .
\end{gathered}
$$

General case for bending of round plates

If the load on the plate or the conditions of its fixation are not axisymmetric, then the plate deflection depends on variables $r, \varphi$ and must satisfy the differential equation

$$
D \Delta \Delta W=q(x, y)
$$

Obviously, we are looking for a solution for a round plate in polar coordinates. The equation (12) in polar coordinates has the form

$$
\left(\frac{\partial^{2}}{\partial r^{2}}+\frac{1}{r} \cdot \frac{\partial}{\partial r}+\frac{1}{r^{2}} \cdot \frac{\partial^{2}}{\partial \varphi^{2}}\right)\left(\frac{\partial^{2} W}{\partial r^{2}}+\frac{1}{r} \cdot \frac{\partial W}{\partial r}+\frac{1}{r^{2}} \cdot \frac{\partial^{2} W}{\partial \varphi^{2}}\right)=\frac{q(r, \varphi)}{D}
$$

or in expanded form

$$
\begin{gathered}
\frac{\partial^{4} W}{\partial r^{4}}+\frac{2}{r^{2}} \cdot \frac{\partial^{4} W}{\partial r^{2} \partial \varphi^{2}}+\frac{1}{r^{4}} \cdot \frac{\partial^{4} W}{\partial \varphi^{4}}+\frac{2}{r} \cdot \frac{\partial^{3} W}{\partial r^{3}}-\frac{2}{r^{3}} \cdot \frac{\partial^{3} W}{\partial r \partial \varphi^{2}}- \\
-\frac{1}{r^{2}} \frac{\partial^{2} W}{\partial r^{2}}+\frac{4}{r^{4}} \cdot \frac{\partial^{2} W}{\partial \varphi^{2}}+\frac{1}{r^{3}} \cdot \frac{\partial W}{\partial r}=\frac{q(r, \varphi)}{D}
\end{gathered}
$$

In the general case of round plates bending to obtain a solution, the deflection of the plate can be represented as a trigonometric Fourier series with respect to the angular coordinate $\varphi$

$$
W(r, \varphi)=W_{0}(r)+\sum_{n=1}^{\infty}\left[\xi_{n}(r) \cos n \varphi+\eta_{n}(r) \sin n \varphi\right]
$$

where the functions $W_{0}(r), \xi_{n}(r)$ and $\eta_{n}(r)$ characterize the change in the plate deflection in the radial direction and they are to be determined.

An arbitrary load $q(r, \varphi)$ causing bending of the plate can also be decomposed into a trigonometric series, similar to the series (14)

$$
q(r, \varphi)=q_{0}(r)+\sum_{n=1}^{\infty}\left[\lambda_{n}(r) \cos n \varphi+\mu_{n}(r) \sin n \varphi\right]
$$

where

$$
\begin{gathered}
{\left[q_{0}(r)=\frac{1}{2 \pi} \cdot \int_{0}^{2 \pi} q(r, \varphi) d \varphi, \quad \lambda_{n}(r)=\frac{1}{\pi} \cdot \int_{0}^{2 \pi} q(r, \varphi) \cos n \varphi d \varphi\right.} \\
\mu_{n}(r)=\frac{1}{\pi} \cdot \int_{0}^{2 \pi} q(r, \varphi) \sin n \varphi d \varphi .
\end{gathered}
$$

Substituting (14), (15) into (13) and comparing the coefficients of linearly independent functions 1 , $\cos n \varphi$, $\sin n \varphi$ we obtain three equations to determine functions $W_{0}(r), \xi_{n}(r)$ и $\eta_{n}(r)$

$$
\frac{d^{4} W_{0}}{d r^{4}}+\frac{2}{r} \frac{d^{3} W_{0}}{d r^{3}}-\frac{1}{r^{2}} \frac{d^{2} W_{0}}{d r^{2}}+\frac{1}{r^{3}} \frac{d W_{0}}{d r}=\frac{q_{0}}{D}
$$




$$
W_{i, n}^{I V}+\frac{2}{r} \cdot W_{i, n}^{\prime \prime \prime}-\frac{\left(2 n^{2}+1\right)}{r^{2}} \cdot W_{i, n}^{\prime \prime}+\frac{\left(2 n^{2}+1\right)}{r^{3}} \cdot W_{i, n}^{\prime}+\frac{n^{2}\left(n^{2}-4\right)}{r^{4}} W=\frac{q_{i, n}}{D},
$$

where

$$
\begin{gathered}
W_{i, n}=W_{i, n}(r), \quad W_{1, n}=\xi_{n}, \quad W_{2, n}=\eta_{n}, \\
q_{i, n}=q_{i, n}(r), \quad q_{1, n}=\lambda_{n}, \quad q_{2, n}=\mu_{n} ; \quad i=1,2 .
\end{gathered}
$$

In equation (16), which describes the plate deflection, the derivatives with respect to the angular coordinate vanish, since $W_{0}$ is a function of $r$ as the coefficient of the Fourier series with respect to $\varphi$. Thus, the function $W_{0}$ describes the axisymmetric bending of a round plate. Note that the partial differential equation (16) coincides with the equation (4).

Equation (17) is an ordinary differential Euler equation. By replacing the variables $r=e^{t}$, equation (17) is reduced to a linear differential equation with constant coefficients

$$
\tilde{W}_{i, n}^{I V}-4 \tilde{W}_{i, n}^{\prime \prime \prime}+2\left(2-n^{2}\right) \tilde{W}_{i, n}^{\prime \prime}+4 n^{2} \tilde{W}_{i, n}^{\prime}+n^{2}\left(n^{2}-4\right) \tilde{W}_{i, n}=\frac{\tilde{q}_{i, n}}{D},
$$

where $\tilde{W}_{i, n}=\tilde{W}_{i, n}(t) ; \tilde{q}_{i, n}=\tilde{q}_{i, n}(t), i=1,2$. The characteristic equation for (18), obviously, has the form

$$
\tau_{i, n}^{4}-4 \tau_{i, n}^{3}+2\left(2-n^{2}\right) \tau_{i, n}^{2}+4 n^{2} \tau_{i, n}+n^{2}\left(n^{2}-4\right)=0 .
$$

In many cases, when solving the problem of bending for a round plate, the accuracy given by the formula (14) is sufficient if there is only the first term of the series (14). If $n=1$, then the characteristic equation (19) has roots $\tau_{i, 1,2}=1, \tau_{i, 3}=3, \tau_{i, 4}=-1$. In this case, the general solution of the differential equation (17) takes the form

$$
W_{i, 1}(r)=A_{i, 1} r+B_{i, 1} r \ln r+K_{i, 1} r^{3}+\frac{L_{i, 1}}{r}+W_{i, 1}^{(1)}(r),
$$

where $A_{i, 1}, B_{i, 1}, K_{i, 1}, L_{i, 1}$ are constants of integration, $W_{i, 1}^{(1)}$ is a partial solution of the equation (17). Constants of integration $A_{i, 1}, B_{i, 1}, K_{i, 1}, L_{i, 1}$ are usually determined from the given boundary conditions, and a partial solution $W_{i, 1}^{(1)}$ depends on the type of load applied to the plate.

If $n=1$ the plate deflection in the general case can be written in the form

$$
\begin{aligned}
W(r, \varphi)= & W_{0}(r)+\left[A_{1,1} r+B_{1,1} r \ln r+K_{1,1} r+\frac{L_{1,1}}{r}+W_{1,1}^{(1)}(r)\right] \cos \varphi+ \\
& +\left[A_{2,1} r+B_{2,1} r \ln r+K_{2,1} r+\frac{L_{2,1}}{r}+W_{2,1}^{(1)}(r)\right] .
\end{aligned}
$$

It should be noted that almost all the problems related to the study of stresses and strains in a plate are reduced to solving boundary value problems for one or several differential equations. The exact solution of these equations does not cause difficulties only in some elementary cases. In more complex cases, finding a solution in analytical form is associated with great mathematical difficulties.

In such cases, it is recommended to use approximate solution methods: variational methods (Ritz method, Galerkin method, Treffz method, Kantorovich method, etc.), which give an approximate analytical expression for the desired function and numerical methods (finite difference method, grid method, variational-difference method, finite element method, etc.), which determine the numerical values of the function for different values of the argument.

\section{References}

1 Awrejcewicz J. Theory of plates and shells: new trends and applications / J. Awrejcewicz, I.V. Andrianov // International Journal of Nonlinear Sciences and Numerical Simulation. - 2014. - 5(1). - P. 23-36. DOI: $10.13140 / 2.1 .2244 .5767$

2 Delale F. Stress analysis of multilayered plates around circular holes / F. Delale // International Journal of Engineering Science. - 1984. - 22(1). - P. 57-75. DOI: 10.1016/0020-7225(84)90132-0

3 Voyiadjis G.Z. Elasto-Plastic and Damage Analysis of Plates and Shells / G.Z. Voyiadjis, P. Woelke. Springer-Verlag Berlin Heidelberg, 2008. - 208 p. DOI:10.1007/978-3-540-79351-9-9 
4 England A.H. Stiffness coefficients for inhomogeneous elastic plates / A.H. England // International Journal of Engineering Science. - 2009. - 47 (3). - P. 1446-1459. DOI: 10.1016/j.ijengsci.2009.10.002

5 Librescu L. A few remarks concerning several refined theories of anisotropic laminated plates / L. Librescu, J.N. Reddy // International Journal of Engineering Science. - 1989. - 27(5). - P. 515-527. DOI: 10.1016 / 0020-7225(89)90004-9

6 Andrianov I.V. Asymptotic Methods in the Theory of Plates with Mixed Boundary Conditions / I.V. Andrianov, J. Awrejcewicz, V.V. Danishevs'kyy, A.O. Ivankov. - Wiley, 2014. - 288 p. DOI: 10.1002 $/ 9781118725184$

7 Громовик А.И. Расчет круглых пластин: метод. указ. / А.И. Громовик. - Омск: СибАДИ, 2011. $33 \mathrm{c.}$

8 Akhanova A.S. On the calculation of plates by the series representation of the deflection function / A.S. Akhanova, G.A. Yessenbayeva, N.K. Tursyngaliyev // Bulletin of the Karaganda University. Mathematics Series. - 2016. - № 2(82). - P. 15-22.

9 Yessenbayeva, G.A. On the calculation of rectangular plates by the variation method / G.A. Yessenbayeva, A.A. Smailova // Bulletin of the Karaganda University. Mathematics Series. - 2016. - № 2(82). P. 56-62.

10 Животов А.Г. О расчете прямоугольных пластин методом тригонометрических рядов / А.Г. Животов, Г.А. Есенбаева // Вестн. Караганд. ун-та. Сер. Математика. - 2015. — № 3(79). - С. 44 49.

11 Косауров А.П. Анализ и особенности методов при расчете пластин и оболочек на изгиб / А.П. Косауров, П.В. Тимофеев. - М.: Фонд «Основание», 2013. - 17 с.

12 Yessenbayeva G.A. On the calculation of the rectangular finite element of the plate / G.A. Yessenbayeva, D.N. Yesbayeva, T.Kh. Makazhanova // Bulletin of the Karaganda University. Mathematics Series. 2018. - № 2(90). - P. 150-156.

13 Завьялов В.Н. Основы строительной механики пластин / В.Н. Завьялов, Е.А. Мартынов, В.М. Романовский. - Омск: СибАДИ, 2012. - 116 с.

14 Тимошенко С.П. Теория упругости / С.П.Тимошенко, Дж. Гудьер. - М.: Наука, 1979. — 560 с.

15 Феодосьев В.И. Сопротивление материалов / В.И. Феодосьев. - М.: Изд-во МГТУ им. Н.Э. Баумана, 1999. - 592 c.

\title{
Г.А. Есенбаева, А.Т. Касимов, Б.А. Касимов
}

\section{Иілу үшін дөңгелек пластиналарды есептеу туралы}

\begin{abstract}
Мақала дөңгелек пластиналардың иілуін зерттеу мәселесіне арналған, пластина механиканың көптеген есептеудің негізі болып табылады. Авторлар осы әдістің құрылымын берген, оның негізгі компоненттерін көрсеткен, сондай-ақ оның түрлері мен классикалық тәсілдерін сипаттаған. Мақалада жеке жағдайларда дөңгелек пластиналардың иілу мәселесі бойынша зерттеу жүргізілді. Дөңгелек пластиналардың иілуін есептеу әдістері, барлық аналитикалық әдістер сияқты, бірнеше артықшылықтарға ие. Негізінен, мақала механиктерге, инженерлерге және техникалық мамандықтары мамандарға бағытталған.
\end{abstract}

Кілт сөздер: дөңгелек пластина, пластинаның иілу функциясы, осьсимметриялық жүктемелер, дөңгелек пластинаның ең жоғары иілуі. 


\section{Г.А. Есенбаева, А.Т. Касимов, Б.А. Касимов}

\section{О расчете круглых пластин на изгиб}

Статья посвящена вопросу исследования изгиба круглых пластин, являющихся основой расчета многих задач механики. Авторами представлена структура данного метода, выделены его основные компоненты, охарактеризованы виды, а также его классические подходы. В статье проведено исследование задачи об изгибе круглых пластин в частных случаях. Методы расчета изгиба круглых пластин, как и все аналитические методы, имеют ряд преимуществ, которые отмечены в статье. Главным образом, статья рассчитана на механиков, инженеров и специалистов технических специальностей.

Ключевые слова: круглая пластина, функция прогиба пластины, осесимметричные нагрузки, максимальный прогиб круглой пластины.

\section{References}

1 Awrejcewicz, J. \& Andrianov, I.V. (2014). Theory of plates and shells: new trends and applications. International Journal of Nonlinear Sciences and Numerical Simulation, 5(1), 23-36.

DOI: $10.13140 / 2.1 .2244 .5767$

2 Delale, F. (1984). Stress analysis of multilayered plates around circular holes. International Journal of Engineering Science, 22(1), 57-75. DOI: 10.1016/0020-7225(84)90132-0

3 Voyiadjis, G.Z. \& Woelke, P. (2008). Elasto-Plastic and Damage Analysis of Plates and Shells. SpringerVerlag Berlin Heidelberg. DOI:10.1007/978-3-540-79351-9-9

4 England, A.H. (2009). Stiffness coefficients for inhomogeneous elastic plates. International Journal of Engineering Science, 47 (3), 1446-1459. DOI: 10.1016/j.ijengsci.2009.10.002

5 Librescu, L. \& Reddy, J.N. (1989). A few remarks concerning several refined theories of anisotropic laminated plates. International Journal of Engineering Science, 27(5), 515-527. DOI: 10.1016/00207225(89)90004-9

6 Andrianov, I.V., Awrejcewicz, J., Danishevs'kyy, V.V. \& Ivankov, A.O. (2014). Asymptotic Methods in the Theory of Plates with Mixed Boundary Conditions. Wiley. DOI: 10.1002/9781118725184

7 Gromovik, A.I. (2011). Raschet kruhlykh plastin: Metodicheskie ukazaniia /Calculation of round plates: Methodical instructions]. Omsk: SibADI [in Russian].

8 Akhanova, A.S., Yessenbayeva, G.A. \& Tursyngaliyev, N.K. (2016). On the calculation of plates by the series representation of the deflection function. Bulletin of the Karaganda University. Mathematics Series, 2(82), 15-22.

9 Yessenbayeva, G.A. \& Smailova, A.A. (2016). On the calculation of rectangular plates by the variation method. Bulletin of the Karaganda University. Mathematics Series, 2(82), 56-62.

10 Zhivotov, A.G. \& Yessenbayeva, G.A. (2015). O raschete pryamouholnykh plastin metodom trihonometricheskikh riadov [On the calculation of rectangular plates by the method of trigonometric series]. Bulletin of the Karaganda University. Mathematics Series, 3(79), 44-49 [in Russian].

11 Kosaurov, A.P. \& Timofeev, P.V. (2013). Analiz i osobennosti metodov pri raschete plastin $i$ obolochek na izhib [Analysis and features of methods for calculation of plates and shells for bending]. Moscow: Fond «Osnovanie» [in Russian].

12 Yessenbayeva, G.A., Yesbayeva, D.N. \& Makazhanova, T.Kh. (2018). On the calculation of the rectangular finite element of the plate. Bulletin of the Karaganda University. Mathematics Series, 2(90), 150-156.

13 Zavyalov, V.N., Martynov, E.A. \& Romanovsky, V.M. (2012). Osnovy stroitelnoi mekhaniki plastin [Basics of structural mechanics of plates]. Omsk: SibADI [in Russian].

14 Timoshenko, S.P. \& Goodier, J. (1979). Teoriia upruhosti [Theory of elasticity]. Moscow: Nauka [in Russian].

15 Feodosyev, V.I. (1999). Soprotivlenie materialov [Strength of materials]. Moscow: Izdatelstvo MHTU imeni N.E. Baumana [in Russian]. 